\title{
Acute Spinal Cord Injury in Rats Induces Autophagy Activation
}

\section{Suçanlarda Akut Omurilik Hasarı Otofaji Aktivasyonunu Indiikler}

\author{
Hongping HOU ${ }^{1,2}$, Lihai ZHANG ${ }^{1}$, Licheng ZHANG ${ }^{1}$, Daohong LIU $^{1}$, Zhi MAO ${ }^{1}$, Hailong DU ${ }^{1}$, Peifu TANG ${ }^{1}$ \\ ${ }^{1}$ Chinese PLA General Hospital, Department of Orthopedics, Beijing, P.R. China \\ ${ }_{2}^{2}$ Medical College, Nankai University, No.94 Weijin Road, Tianjin 300071, PR China
}

Corresponding Author: Tang PEIFU / E-mail: pftang301@126.com

\begin{abstract}
AIM: Autophagy is an important process that balances cellular protein synthesis and degradation and is involved in many physiological and pathological conditions. However, the precise role of autophagy has not yet been defined in the model of spinal cord injury (SCI).

MATERIAL and METHODS: Here, we utilized a hemisection model of acute SCI to elucidate the role of autophagy in the pathological processes underlying $\mathrm{SCl}$.

RESULTS: LC3B-II, a well-known marker of autophagy, was immunohistochemically detected $4 \mathrm{H}$ after SCI, peaked at 3D, and decreased at 21D. Hematoxylin-eosin (HE) staining confirmed accurate spinal cord hemisection, which was accompanied by both neuronal swelling and shrunken neurons with darkly stained, condensed nuclei. These findings suggest that the process of autophagy is related with pathological changes following $\mathrm{SCl}$.
\end{abstract}

CONCLUSION: Our results indicate autophagy is involved in the pathological changes after $\mathrm{SCl}$, and potential therapies to promote neuronal regeneration following $\mathrm{SCl}$ should target the mechanism of autophagy.

KEYWORDS: Acute spinal cord injury, Autophagy, LC3, Neuronal regeneration, HE staining, Rat

öz

AMAÇ: Otofaji, hücre protein sentezini ve degradasyonunu dengeleyen önemli bir süreçtir ve birçok fizyolojik ve patolojik durumla ilişkilidir. Ancak otofajinin omurilik yaralanması modelinde tam rolü tanımlanmamıştır.

YÖNTEM ve GEREÇLER: Burada otofajinin omurilik yaralanmasının temelindeki patolojik süreçlerdeki rolünü açıklığa kavuşturmak üzere akut omurilik yaralanması için bir hemiseksiyon modeli kullandık.

BULGULAR: Otofajinin iyi bilinen bir işareti olan LC3B-II, omurilik yaralanmasından 4 saat sonra immünohistokimyasal olarak saptandı, 3 günde tepe düzeye çıktı ve 21 günde azaldı. Hematoksilen eozin (HE) boyama hassas omurilik hemiseksiyonunu doğruladı ve beraberinde hem nöronal şişme hem de koyu boyanan, kondanse çekirdekli küçülmüş nöronlar vardı. Bu bulgular otofaji sürecinin omurilik yaralanmasında patolojik değişikliklerle ilişkili olduğunu düşündürmektedir.

SONUÇ: Sonuçlarımız otofajinin omurilik yaralanması sonrasında patolojik değişikliklerle ilgili olduğuna işaret etmektedir ve omurilik yaralanması sonrasında nöron rejenerasyonunu desteklemek amaçlı potansiyel tedaviler otofaji mekanizmasını hedeflemelidir.

ANAHTAR SÖZCÜKLER: Akut omurilik yaralanması, Otofaji, LC3, Nöron rejenerasyonu, HE boyama, Sıçan

\section{INTRODUCTION}

Autophagy is a cellular "self-eating" of damaged organelles and long-lived proteins $(15,17)$ and is known to participate in various diseases, such as cancer (17), infection (12), heart disease (1), and vascular disease (9). Autophagy is a static metabolism process during periods of nutrient availability, when it eliminates dysfunctional or damaged organelles and long-lived proteins. During times of nutrient deprivation, autophagy increases and recycles aging proteins back to their amino acid and fatty acid constituents to sustain the cell (25). In addition, autophagy can suppress tumor development, eliminate bacterial infection, and is involved in ischemiareperfusion injury. Recently, many studies have investigated autophagy activation during neuronal regeneration. For example, autophagy is deregulated with aging, and enhanced autophagy may slow down the symptoms of Alzheimer's disease $(7,20,27)$. Conversely, in a model of Parkinson's disease $(4,5,11,30)$, the expression of autophagy-related proteins was upregulated, suggesting that the process was enhanced.

Here, we determined whether autophagy was activated in a model of acute spinal cord injury (SCI). Light chain 3 (LC3) was used to assess the time course of autophagy following spinal cord hemisection at different time points. Hematoxylin-eosin (HE) staining was performed to investigate the relationship between autophagy and pathological changes. These results are to elaborate the role of autophagy in the process of pathological changes after $\mathrm{SCl}$. 


\section{MATERIAL and METHODS}

\section{Animals' Preparation and Operation}

All procedures were in compliance with the guidelines for animal scientific procedures approved by the host institution's ethical committee. A total number of 48 Sprague Dawley rats weighing $200-250 \mathrm{~g}$ were randomly divided into two groups: control (laminectomy only) and $\mathrm{SCl}$ group, which included five sub-groups, 4H (hour), 3D (day), 7D, 14D and 21D after injury. Before surgery, all animals were housed three or four per cage for 1 week to adapt to the new environment $\left(25^{\circ} \mathrm{C}\right.$ on a 12-h light/dark cycle).

Mice were anesthetized with $10 \%$ pentobarbital sodium (300 $\mathrm{mg} / \mathrm{kg}$, intraperitoneal [i.p.]) (28). The skin was sterilized, and an incision was made to expose the dorsal muscles, which were then divided in layers. A laminectomy was performed at the T9-T10 level with the help of a dissecting microscope to expose the spinal cord. A dorsal hemisection (right side) was performed at T9-T10 (16), and residual fibers were removed from the lesion site. After that, the muscles and skin were sutured in layers. During surgery, body temperature was recorded and maintained at $37^{\circ} \mathrm{C}$ with a heating pad. Following surgery, the bladder was manually expressed three times a day until self-voiding bowel function recovery. The control group was also operated on, but the spinal cord was not hemisected.

\section{Tissue Preparation}

After surgery, animals at each time point were transcardially perfused with physiological saline solution followed by $4 \%$ paraformaldehyde in $0.1 \mathrm{M}$ phosphate buffer (PB). About 1.5 centimeters of spinal cord around the lesion site was collected and immersed in the same fixative for further sectioning. The spinal cord samples were then postfixed in $30 \%$ sucrose in phosphate-buffered saline (PBS) overnight until the tissue sank. Next, the samples were frozen, and serial 20- $\mu \mathrm{m}$ transverse and longitudinal sections were taken around the $\mathrm{SCl}$ epicenter and mounted on slides.

\section{Immunohistochemistry}

For further immunohistochemical staining, the samples were washed in PBS three times for 5 min each and boiled in $0.1 \%$ Trisodium citrate for $15 \mathrm{~min}$ for antigen retrieval. Next, the samples were incubated with blocking reagent for $1 \mathrm{~h}$ at room temperature and further incubated with anti-LC3 polyclonal rabbit antibody (1:200, Sigma, St. Louis, MO, USA) at $4^{\circ} \mathrm{C}$ overnight. Next, sections were washed with $0.01 \%$ Tween 20 in PBS and then immersed with TRITC goat-rabbit IgG secondary antibody for $1 \mathrm{~h}$. Then, the sections were counterstained with DAPI to identify cell nuclei. After the slides were sealed, the sections were imaged with a confocal microscope. LC3-positive cells were counted in 100 sections per animal and then the percentage of LC3-positive cells was averaged in all 8 animals.

\section{HE Staining}

The procedures were performed following the manufacturers' guidelines. In brief, the sections were washed with PBS three times for 5 min each, followed by hematoxylin for 5 minutes and eosin for another $5 \mathrm{~min}$ at room temperature. After three more 5-min washes in PBS, sections were quickly differentiated in $95 \%$ alcohol, made transparent in dimethylbenzene, and sealed with neutral resin. Finally, the percentage of damaged cells were counted in 100 sections per animal and averaged for further analysis in all 8 animals.

\section{Statistical Analysis}

All images were analyzed using Image pro plus software. Data were reported as Mean \pm Standard Deviation (SD). Significant differences among time points were assessed by analysis of variance (ANOVA) with SPSS software17.0, and $p<0.05$ was considered statistically significant ("and " indicate $p<0.05$ and $p<0.01$, respectively).

\section{RESULTS}

\section{LC3 Upregulation After Acute SCI}

Over time, the percentage of cells with punctate LC3B-II gradually increased near the wound site (Figure $1 A, B$ ). In the control group, LC3B-II remained at basal level; there were only a few cells with punctate LC3B-II immunoreactivity. However, in the acute $\mathrm{SCl}$ group, the percentage of LC3B-II positive cells was higher than the control group for all time points. At $4 \mathrm{H}$ after injury, the percentage of positive cells was increased; it peaked at 3D, and began to decrease at 7D and 21D after SCl. Collectively, the results indicate that the potential primary and secondary pathological mechanisms of $\mathrm{SCl}$ activated the process of autophagy.

\section{Histological Changes in SCI}

HE staining was used to investigate histological changes after acute $\mathrm{SCl}$. Neurons of gray matter in the control group appeared normal, with intact, round, full nuclei and clear nucleoli. However, $\mathrm{SCl}$ induced histological changes near the injury site, including neuronal swelling and shrunken neurons with darkly stained, condensed nuclei. Meanwhile the tissues seemed disorderly and irregularly arranged (Figure $2 \mathrm{~A}, \mathrm{~B}$ ). In white matter, the glia cells were also damaged after $\mathrm{SCl}$. At $4 \mathrm{H}$ after injury, there was evidence of slight neuronal and glia cells losses in the injury site. HE staining showed massive astrocytes infiltration. After 3D, there were significant losses and damage of neurons and glia cells, which were replaced by numerous macrophages. In addition, after 7D and $21 \mathrm{D}$, with partial blood flow recovery, neurons and glia cells had gradual recovery.

\section{DISCUSSION}

Autophagy is characterized by the processes of initiation, elongation, closure (double membranes), maturation (fusion of autophagosome and lysosome), and degradation. Among them, double membrane formation is essential for autophagy activation. The aggregation of Atg8 protein, also known as 


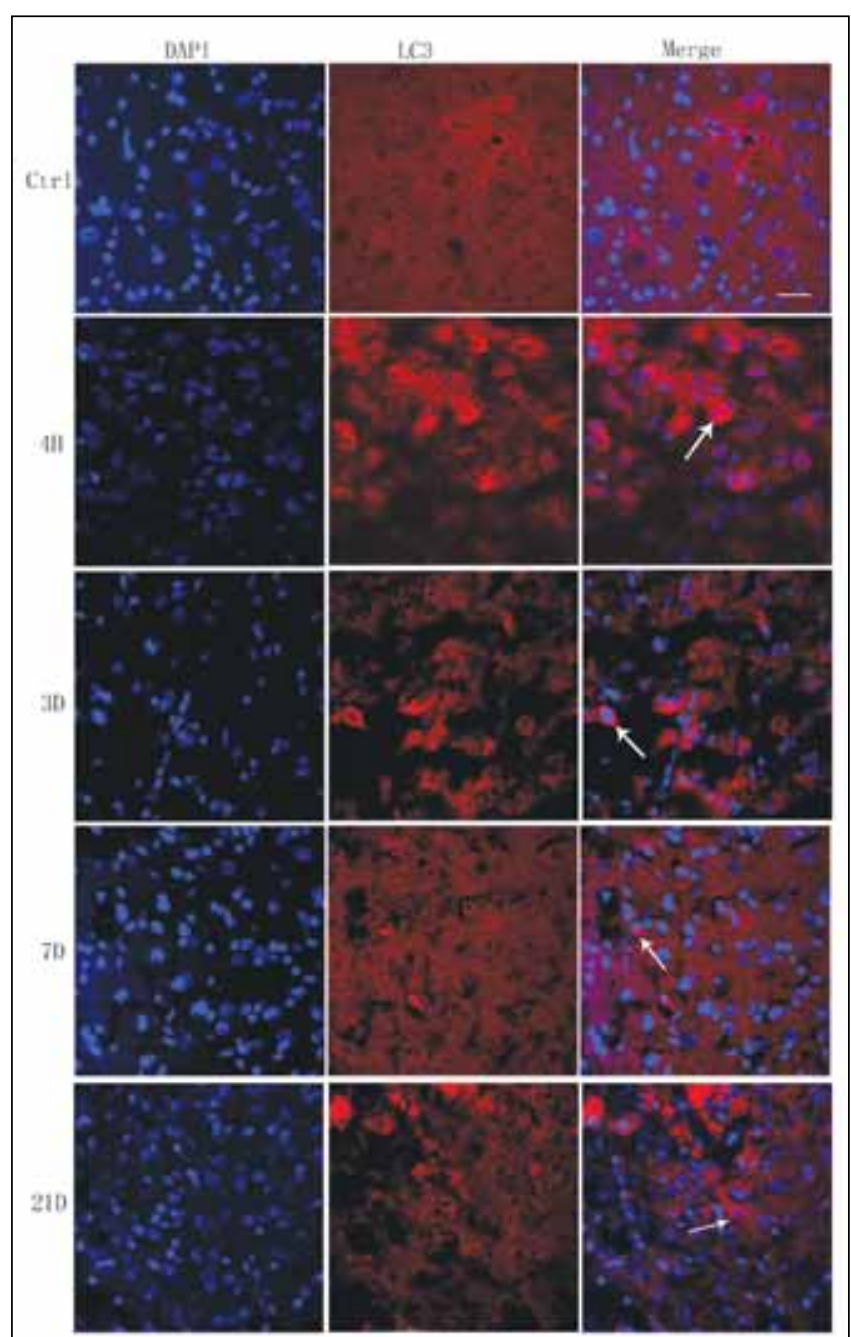

(A)

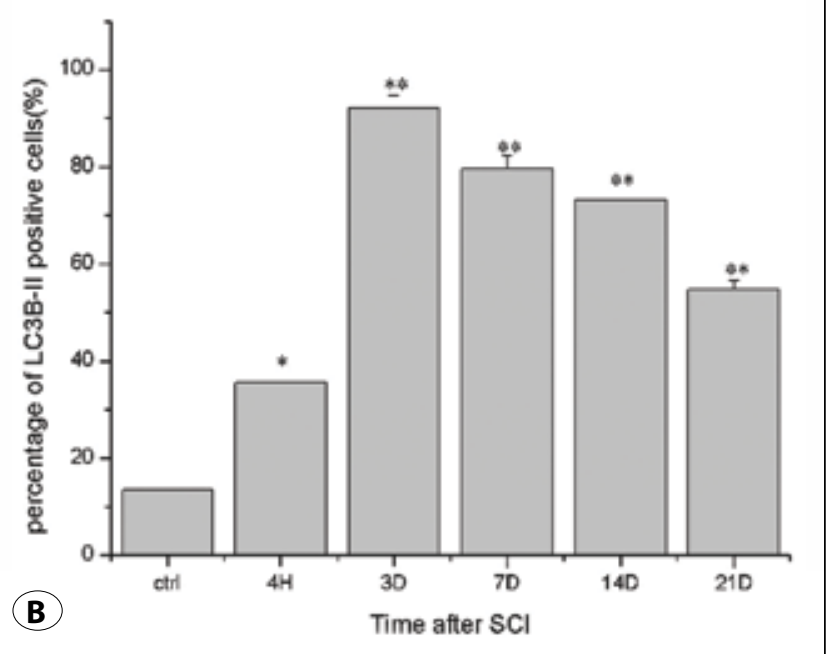

Figure 1: LC3B-II expression near the injury site at each time point. A) Cells with punctate LC3B-Il expression in the control and $\mathrm{SCl}$ groups at 4H, 3D, 7D and 21D after injury (scale bar=20um, arrows show the positive cells). B) Quantitative analysis of percentage of LC3B-II positive cells. Values represent the Means \pm SD. ${ }^{*} p<0.01,{ }^{* *} p<0.05$.

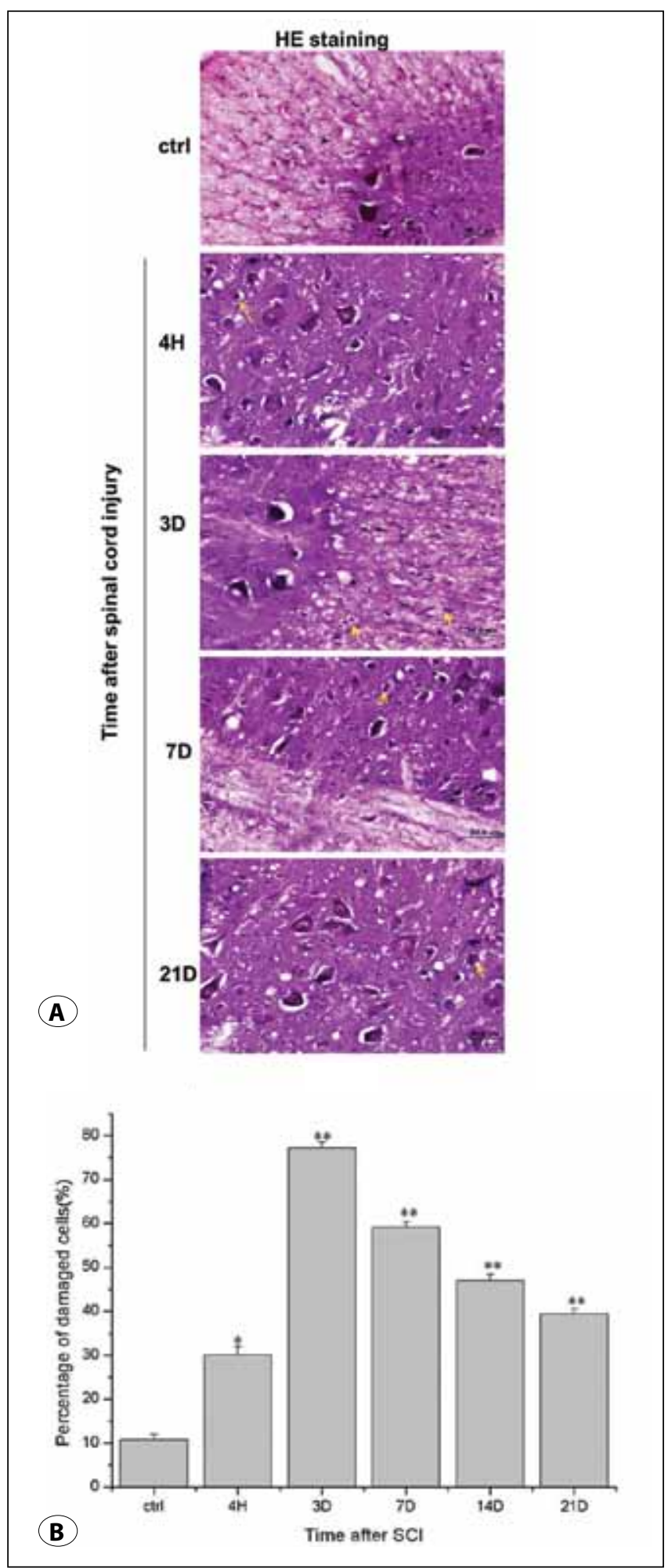

Figure 2: Histopathological changes in the control and $\mathrm{SCl}$ groups at $4 \mathrm{H}, 3 \mathrm{D}, 7 \mathrm{D}$, and 21D after injury. A) At 4H and 3D after surgery, the neurons and glia cells gradually disappeared. At 7D and 21D as blood flow recovered, the neurons and glia cells appeared more normal (scale bar $=50$ um, arrows show the damaged cells). B) Quantitative analysis of percentage of damaged cell. ${ }^{*} p<0.01,{ }^{* *} p<0.05$. 
microtubule-associated protein 1 light chain 3 (LC3), is the hallmark of autophagosome formation. LC3 is initially synthesized in an unprocessed form, proLC3, which is converted into a proteolytically processed form lacking $C$ terminus amino acids, LC3-I, and is finally modified into the phosphatidylethanolamine (PE)-conjugated form, LC3-II (LC3-I, unlipidated; LC3-II, lipidated) (18). Previous studies assessed LC3 upregulation to study autophagy induction in various disease models $(2,10)$.

We employed an acute model of $\mathrm{SCl}$ to determine whether autophagy was induced. In our model system, LC3BII expression gradually increased with time. Autophagy induction occurred $4 \mathrm{H}$ after injury, peaked at 3D, and declined at 7D and 21D after injury. At the same time, HE staining revealed that the process of autophagy was correlated with the pathological changes. All of these results demonstrate that autophagy activation played an important role in the pathological changes after $\mathrm{SCl}$ and may also be involved in the process of neuronal regeneration.

Autophagy has become an important research topic because of the discovery of those components involved in recycling cellular damaged organelles and long-lived proteins (24). This process has an important role in many pathological conditions. In tumor development, autophagy has two different roles; it can promote tumor cells survival and facilitate tumor suppression (13,26,29). In Alzheimer's disease, the expression of proteins involved in the autophagic pathway is decreased, and there is evidence that over-activation of autophagy may slow down the symptoms of memory loss and behavioral dysfunction $(23,27)$. In other models of neuronal injury, autophagy was induced and participated in the processes of neuronal regeneration and behavioral recovery (25). In neonatal hypoxia-ischemia-induced brain injury, enhanced beclin 1 expression and switching the mechanisms of cell death from apoptosis to necrosis may explain why autophagic processes facilitate neuronal recovery.

In other nervous system injuries $(14,19)$, autophagy was highly activated in both neurons and astrocytes. In a model of closed head injury, Beclin1 was upregulated at cortical injury sites (6). Upregulation of Beclin 1 and LC3 in a model of focal cerebral ischemia may represent enhanced autophagy either as a mechanism to discard injured cells or to reduce neuronal damage (22). In traumatic brain injury, elevation of Beclin1 suggests that autophagic pathways are involved in the processes of neuronal loss and regeneration (8).

In neonatal hypoxia-ischemia induced brain injury, the inhibitor of autophagy 3-MA has been used to investigate the role of autophagy in brain injury (3). The results indicate that in the early stage of brain injury, autophagy over-activation may have a potentially protective role. Conversely, in a model of neonatal cerebral ischemia, inhibition of autophagy had a neuroprotective effect (21). Autophagy has been shown to play different roles depending on the models employed and experiment timing (24). In future studies, we hope to elucidate the role of autophagy in acute $\mathrm{SCl}$, specifically its effect on neuronal recovery.
In conclusion, autophagy activation was observed over time in our model of acute spinal cord injury. Cells with punctate LC3B-II appeared at 4H, peaked at 3D, and decreased at 7D and $21 \mathrm{D}$ after injury.

\section{ACKNOWLEDGEMENTS}

This research was supported by the Natural Science Foundation of China (No. 30973068) and general projects of the twelve-fifth scientific plan in army medical science and technology (No. CWS11J101).

\section{REFERENCES}

1. Bao XH, Naomoto $Y$, Hao HF, Watanabe N, Sakurama K, Noma $\mathrm{K}$, et al: Autophagy: Can it become a potential therapeutic target? Int J Mol Med 25:493-503, 2010

2. Berglund L, Bjorling E, Oksvold P, Fagerberg L, Asplund A, Szigyarto CA, et al: A genecentric Human Protein Atlas for expression profiles based on antibodies. Mol Cell Proteomics 7:2019-2027, 2008

3. Carloni S, Buonocore G, Balduini W: Protective role of autophagy in neonatal hypoxia-ischemia induced brain injury. Neurobiol Dis 32:329-339, 2008

4. Chan NC, Salazar AM, Pham AH, Sweredoski MJ, Kolawa NJ, Graham RL, et al: Broad activation of the ubiquitinproteasome system by Parkin is critical for mitophagy. Hum Mol Genet 20:1726-1737, 2011

5. Cheung ZH, Ip NY: Autophagy deregulation in neurodegenerative diseases - recent advances and future perspectives. J Neurochem 118:317-325, 2011

6. Diskin T, Tal-Or P, Erlich S, Mizrachy L, Alexandrovich A, Shohami $E$, et al: Closed head injury induces upregulation of Beclin 1 at the cortical site of injury. J Neurotrauma 22: 750-762, 2005

7. Edwards HV, Cameron RT, Baillie GS: The emerging role of HSP20 as a multifunctional protective agent. Cell Signal 23:1447-1454, 2011

8. Erlich S, Shohami E, Pinkas-Kramarski R: Neurodegeneration induces upregulation of Beclin 1. Autophagy 2:49-51, 2006

9. Eskelinen EL, Saftig P: Autophagy: A lysosomal degradation pathway with a central role in health and disease. Biochim Biophys Acta 1793:664-673, 2009

10. Funk KE, Mrak RE, Kuret J: Granulovacuolar degeneration (GVD) bodies of Alzheimer's disease (AD) resemble late-stage autophagic organelles. Neuropathol Appl Neurobiol 37: 295-306, 2011

11. Kim-Han JS, Antenor-Dorsey JA, O'Malley KL:The Parkinsonian mimetic, MPP+, specifically impairs mitochondrial transport in dopamine axons. J Neurosci 31:7212-7221, 2011

12. Kundu M, Thompson CB: Autophagy: Basic principles and relevance to disease. Annu Rev Pathol 3:427-455, 2008

13. Larsen CJ: Autophagy: A necessary allied in the growth of pancreatic adenocarcinoma. Bull Cancer 98:719-722, 2011

14. Levine B, Kroemer G: Autophagy in the pathogenesis of disease. Cell 132:27-42, 2008 
15. Mehrpour M, Esclatine A, Beau I, Codogno P: Autophagy in health and disease. 1. Regulation and significance of autophagy: An overview. Am J Physiol Cell Physiol 298:C776-C785, 2010

16. Merkler D, Metz GA, Raineteau O, Dietz V, Schwab ME, Fouad $\mathrm{K}$ : Locomotor recovery in spinal cord-injured rats treated with an antibody neutralizing the myelin-associated neurite growth inhibitor Nogo-A. J Neurosci 21:3665-3673, 2001

17. Mijaljica D, Prescott M, Devenish RJ: Autophagy in disease. Methods Mol Biol 648:79-92, 2010

18. Mizushima N, Yoshimori T, Levine B: Methods in mammalian autophagy research. Cell 140:313-326, 2010

19. Napoletano F, Occhi S, Calamita P, Volpi V, Blanc E, Charroux $B$, et al: Polyglutamine Atrophin provokes neurodegeneration in Drosophila by repressing fat. EMBO J 30:945-958, 2011

20. Neely KM, Green KN, LaFerla FM: Presenilin is necessary for efficient proteolysis through the autophagy-lysosome system in a gamma-secretase-independent manner. J Neurosci 31:2781-2791, 2011

21. Puyal J, Vaslin A, Mottier V, Clarke PG: Postischemic treatment of neonatal cerebral ischemia should target autophagy. Ann Neurol 66:378-389, 2009

22. Rami A, Langhagen A, Steiger S: Focal cerebral ischemia induces upregulation of Beclin 1 and autophagy-like cell death. Neurobiol Dis 29:132-141, 2008
23. Scheper W, Nijholt DA, Hoozemans JJ: The unfolded protein response and proteostasis in Alzheimer disease: Preferential activation of autophagy by endoplasmic reticulum stress. Autophagy 7:910-911, 2011

24. Shintani T, Klionsky DJ: Autophagy in health and disease: A double-edged sword. Science 306:990-995, 2004

25. Smith CM, Chen Y, Sullivan ML, Kochanek PM, Clark RS: Autophagy in acute brain injury: Feast, famine, or folly? Neurobiol Dis 43:52-59, 2011

26. Sun PH, Zhu LM, Qiao MM, Zhang YP, Jiang SH, Wu YL, et al: The XAF1 tumor suppressor induces autophagic cell death via upregulation of Beclin-1 and inhibition of Akt pathway. Cancer Lett 310:170-180, 2011

27. Tamboli IY, Tien NT, Walter J: Sphingolipid storage impairs autophagic clearance of Alzheimer-associated proteins. Autophagy 7:645-646, 2011

28. Teng YD, Lavik EB, Qu X, Park KI, Ourednik J, Zurakowski D, et al: Functional recovery following traumatic spinal cord injury mediated by a unique polymer scaffold seeded with neural stem cells. Proc Natl Acad Sci U S A 99:3024-3029, 2002

29. Wei H, Wei S, Gan B, Peng X, Zou W, Guan JL: Suppression of autophagy by FIP200 deletion inhibits mammary tumorigenesis. Genes Dev 25:1510-1527, 2011

30. Xilouri $M$, Stefanis L: Autophagic pathways in Parkinson disease and related disorders. Expert Rev Mol Med 13:e8, 2011 